Review Article

\title{
Nematicides: history, mode, and mechanism action
}

\author{
Luciano Antônio Ebone, Marcos Kovaleski, Carolina Cardoso Deuner
}

Faculty of Agronomy and Veterinary Medicine, Post-Graduate Program in Agronomy, University of Passo Fundo, Passo Fundo - RS, Brazil

\section{Article history}

Received: 25 December 2018

Accepted: 27 February 2019

Published: 01 April 2019

\section{Editor}

Dr. Eman Bazh

Menoufia University

Al Minufya, Egypt

\section{Publisher}

Horizon e-Publishing Group

\section{*Correspondence}

Luciano Antônio Ebone

\lucianoebone9@gmail.com

\begin{abstract}
Nematodes are non-segmented invertebrate animals, which are one of the major phytosanitary problems worldwide, especially in tropical and subtropical regions, attacking the root system of plants they removing photo-assimilates and reducing the absorption capacity of water and nutrients of plant. In order to avoid economic losses by reducing productivity and quality, synthetic compounds have been developed to control nematodes. The use of these synthetic compounds, known as chemical control, has high economic importance, being the current tool most used by farmers for control of these individuals. Moreover, only in Brazil, the trade of these products reaches hundreds of millions of dollars per year. This review aims to address the fundamental aspects of nematode biology and the chemical control of the major genus (Meloidogyne, Heterodera, and Globodera). It covers the historical evolution of the chemical control agents since its beginning in the nineteenth century until today, their mode of action (fumigants and nonfumigants), mechanisms of action (inhibition of the acetylcholinesterase enzyme, opening of the chloride channel, inhibition of electron transport in the electron transport chain, enzymatic inactivation, as a Dauer phase-inducing agent or agent that ensures the organism remains irreversibly in the Dauer phase), the products available for each crop, including their commercial names and forms of application.
\end{abstract}

Keywords: abamectin; carbamates; fumigants; non-fumigants; nematodes; organophosphates

Citation: Ebone LA, Kovaleski M, Deuner CC. Nematicides: history, mode, and mechanism action. Plant Science Today 2019;6(2):91-97. https://doi.org/10.14719/pst.2019.6.2.468

Copyright: (c) Ebone et al (2019). This is an open-access article distributed under the terms of the Creative Commons Attribution License, which permits unrestricted use, distribution, and reproduction in any medium, provided the original author and source are credited (https://creativecommons.org/licenses/by/4.0/).

Indexing: Plant Science Today is covered by Scopus, CAS, AGRIS, CABI, Google Scholar, etc. Full list at http://www.plantsciencetoday.online

\section{Introduction}

Nematodes are non-segmented invertebrate animals (1). Parasitic-plant nematodes are small, typically $300-1,000 \mu \mathrm{m}$ in length, although some are up to $4 \mathrm{~mm}$ long, by 15-35 $\mu \mathrm{m}$ in width (2). Nematodes possess a relatively simple anatomy ("tube within a tube"), characterized as limbless, cylindrical, and elongated (3).

Fossil records show that the first parasitic relationships between nematodes and plants occurred approximately 150 million years ago (4). Today, the main phytopathogenic nematodes in economic terms are root-knot nematodes (Meloidogyne spp.), followed by cyst nematodes (Heterodera and Globodera spp.), root lesion nematodes (Pratylenchu spp.), the burrowing nematode (Radopholus similis Cobb), and the stem nematode (Ditylenchus dipsaci Filipjev) (5).

The parasitism occurs by insertion of the stylet (spear-like structure attached to the mouth of the nematode) into the plant tissue (6). The 
parasitism relationships established between these antagonistic individuals cause serious damage to the infested plant. The nematodes can trigger two kinds of symptoms; direct symptoms, such as a reduction of root mass, a distortion of root structure, and enlargement of the roots, or indirect symptoms, which include a deficiency in absorption water and nutrients (7). Usually, the infestation will occur in circles in the area, and not throughout the entire crop.

Although the infestation takes place in the host's root system, this infestation is covered by soil. Hence, the reflex symptoms seen in the shoot are the guidelines for the investigation of the presence of nematodes in the area. An investigation into the root-knot nematode (Meloidogyne enterolobii) induced decay of the guava (Psidium guajava L.) observed that due to the parasite's action on the tree's roots, visual symptoms were noticed, including yellow leaves or red spots, necrosis, wilting and premature leaf abscission, loss of vigor (8).

Due to the problems caused by nematodes, they are considered as important pathogens in many crops (9), for example, soybean (Glycine max (L). Merr.) (10), coffee (Coffea arabica L.) (11), and sugarcane (Saccharum sp.) (12). In some crops and localities, these animals may even be the main phytosanitary problem. For example, the cereal cyst nematode (Heterodera avenae Woll.) is the main pathogen of wheat (Triticum aestivum L.) and barley (Hordeum vulgare L.) in the Middle East, reducing yields by up to $92 \%$, in extreme cases (13). It was estimated that nematodes generate a projected yield loss of $12.3 \%$ (US\$157 billion dollars) worldwide (14).

As a result of the extensive damage caused by these organisms, the synthesis of compounds and test products aimed at controlling nematodes began in the nineteenth century as a way to ensure food safety and avoid economic losses. Originally applied to the soil, these substances had the objective of sterilizing the soil, thereby removing any pests and phytoparasites, including phytonematodes (15). Thus, the use of such chemical agents in agriculture had a major impact on agricultural production, improving the yield and quality of crops worldwide (16).

Fumigant nematicides, such as methyl bromide, were the first to be used in crops to control nematodes and were widely applied to high-value crops, like tobacco (17). However, these products presented problems, like environmental toxicity and high risks to the applicators (18). From the 1940s onwards, strategies were sought to improve the application technology as a way to reduce the toxicity. Methods for applying these liquid products through agricultural implements coupled with injector nozzles at different depths were developed (15).
Afterward, products with other nematicidal properties were developed that were less toxic and without a vapor phase. These so-called nonfumigant nematicides are represented by two main classes of chemical compounds: organophosphates (terbufos, ethoprophos, fenamiphos) and carbamates (aldicarb, carbofuran, carbosulfan, oxamyl) (16), and widely used in Brazil, mainly in sugarcane, maize (Zea mays L.) soybean, and cotton (Gossypium hirsutum L.). It is worth highlighting the emergence of more recent compounds, such as fluensulfone, which have started to compete for the market, especially for application in sugarcane (15).

It is important to note that some insecticidal products also present nematicidal action, like abamectin and imidaclopridthiodicarb. These products are intended for seed treatments for cotton, maize, and soybean, acting on species of Meloidogyne incognita (Chitwood), Meloidogyne javanica (Chitwood), Pratylenchus brachyurus (Filipjev \& Stekhoven), and Rotylenchus reniformis (Linford \& Oliveira), among others (15).

This article discusses the history of chemical control of nematodes, covering the mode and mechanism of action of nematicides, and the forms of application.

\section{History of chemical control}

Chemical control is an important tool in nematode control. It is considered as one of the most effective and reliable control techniques within integrated management (19). The use of chemical agents began in 1881, with carbon disulfide, which was the first product identified with nematicidal properties (16). At the time, it was used to treat soil for the control of Filoxera sp. in grapevine (Vitis vinifera L.). Another chemical tested in the control of nematodes due to its nematicidal properties was chloropicrin (trichloronitromethane) (20).

Methyl bromide is classified as a pesticide of restricted use and registered as a herbicide, nematicide, insecticide, and fungicide (21). It started to be used in the early 1940s and was once the most popular nematicide in the USA (17). The production and use of methyl bromide were eliminated internationally in developed countries in 2005 because the chemical was categorized as a Class I ozone-depleting substance by the Montreal Protocol (21).

Since its elimination, a significant amount of research has been devoted to finding alternative fumigants to methyl bromide. Much of this research was focused on the evaluation of existing fumigants that had limited use while methyl bromide was available, such as 1,3dichloropropene, metam sodium, and chloropicrin, as well as some new fumigants, for 


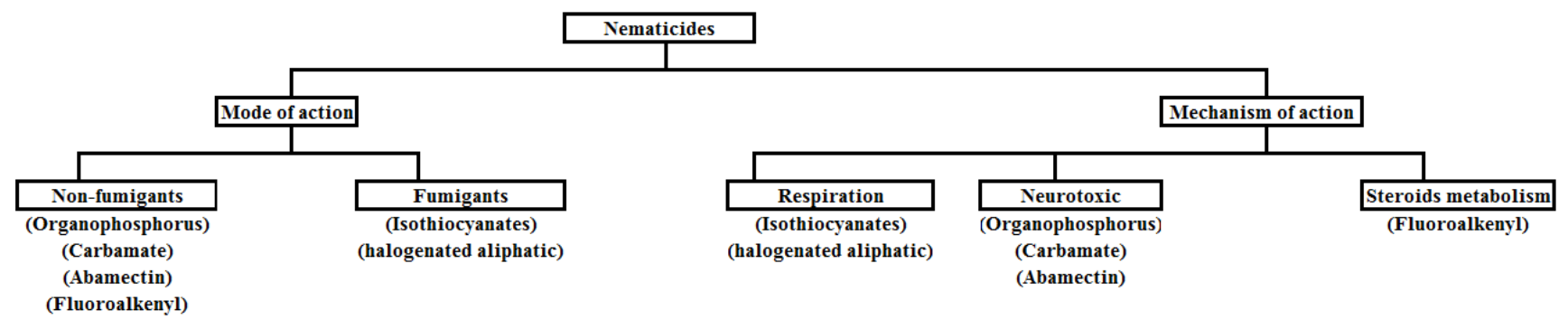

Fig. 1. Mode and mechanism of action of the main nematicide groups.

instance, dimethyl disulfide and allyl isothiocyanate (22).

Despite the efficiency of fumigants in nematode control, the application difficulties associated with the high costs and high environmental risk of these extremely toxic products resulted in the reduction of their use (18).

Based on difficulties in the management of fumigant nematicides, such as the control of its application and the high toxicity of this group, after the second half of the 20th century, two new classes of nematicides were developed: organophosphates and carbamates. Less toxic and without a vapor phase, they came to be called nonfumigant nematicides (23). The first active ingredient of the non-fumigant nematicides was $O$ 2,4-dichlorophenyl $O, O$-diethyl phosphorothioate, which was commercialized in 1957 (17).

In Brazil, the management of nematodes is done by using nematicides to treat the seeds or via their application in the planting groove; another technique includes the use of resistant cultivars or crop rotation (23). In the case of cotton, in situations of technical or economic impossibility of the use of management practices, the application of nematicides cannot be neglected, because it can generate increases of up to $10 \%$ in crop productivity (24). Applying nematicides at planting of sugarcane in areas infested by nematodes can result in agricultural productivity increases of $40 \mathrm{t} /$ ha (25).

In research studies with abamectin-based products, despite good control effectiveness, the emulsifiable concentrate formulations with $18 \%$ or $36 \%$ active ingredient may lead to phytotoxicity when used for seed treatment (26). In addition, it was found that a large part of the abamectin applied via seed treatment remains adhered to the seed coat (27).

A limited number of crops are the main consumers of nematicides, such as sugarcane, corn, and soybeans (which together account for $90 \%$ of the market for chemical nematicides), as well as cotton, coffee, potatoes (Solanum tuberosum L.), citrus, and rice (Oryza sativa L) (15). More products have appeared in recent years, for instance, benfuracarb and fluensulfone, which have been proven effective against nematode control in sugarcane and other crops (15).
Data on the chemical composition, extensions of use, recommended doses, and modes of application of agents for the control of nematodes is regularly updated by Brazil's Ministry of Agriculture, Livestock, and Supply (MAPA). This list contains 16 registered chemical nematicides in commercial use (Table 1), although not all are still present in the market (028). The products include aldicarb (banned), methyl bromide (for quarantine use only), cadusafos, carbofuran, carbosulfan, dazomet, ethoprophos, fenamiphos, fluensulfone, phorate, fosthiazate, isazofos (banned), metamodic, oxamyl (no commercial product), terbufos, and triazophos.

\section{Mode of action}

The mode of action of all products is essentially similar (21). The nematicides applied directly to the soil are classified into two distinct categories (Fig. 1) based on their movement in the soil, such as fumigants and non-fumigants (23).

In general, fumigant nematicides are liquid formulations that are vaporized when they come in contact with the air (23). By the detachment of their molecules in the vapour phase, they move in the soil usually in depth, and when they are exposed to the water available in the soil, they decompose into products that penetrate directly into the cuticle of the nematode, reacting rapidly with amino acids, oxidases, and proteins, causing metabolic dysfunctions (23).

Fumigant nematicides are considered biocidal substances, acting on fungi, bacteria, seeds, and other organisms present in the soil and, when applied in can cause environmental disturbance and phytotoxicity (29). Fumigants perform better on soils that do not have high levels of organic matter because they react with nucleophilic sites in soil organic matter (-SH, $-\mathrm{NH}_{2}$, -OH, -COO-). The same happens with clay, especially 2:1 clay mineral, which has the capacity to adsorb fumigants (30). In general, fumigants are more effective in soils with temperatures above 12 or $15{ }^{\circ} \mathrm{C}$ since the dispersion is related to temperature (31).

Broad-spectrum fumigant nematicides penetrate directly into the body wall of the nematode and do not need to be ingested to be effective. Once inside the cavity of the nematode 
Table 1. List of active ingredients registered for nematode control.

\begin{tabular}{|c|c|c|c|}
\hline Chemical group & Common name & Crop & Commercial Name \\
\hline \multicolumn{4}{|l|}{ Organophosphorus } \\
\hline & Cadusafos & $\begin{array}{l}\text { Cotton, potato, coffee and } \\
\text { sugar cane }\end{array}$ & $\begin{array}{l}\text { Apache } 100 \text { GR, Rugby } 100 \\
\text { GR, Rugby } 200 \text { CS }\end{array}$ \\
\hline & Ethoproph & Potato. & Rhocap \\
\hline & Fenamiphos & $\begin{array}{l}\text { Cotton, banana, potato, } \\
\text { coffee, melon and tomato. }\end{array}$ & Nemacur, Nemacur EC \\
\hline & Phorate & $\begin{array}{l}\text { Cotton, peanuts, potatoes, } \\
\text { coffee, beans, corn, tomatoes } \\
\text { and wheat. }\end{array}$ & Granutox \\
\hline & Fosthiazate & $\begin{array}{l}\text { Banana, potato, coffee, } \\
\text { carrot. }\end{array}$ & Cierto 100 GR \\
\hline & Terbufos & $\begin{array}{l}\text { Cotton, peanuts, bananas, } \\
\text { coffee, sugar cane, beans } \\
\text { and corn. }\end{array}$ & Counter $150 \mathrm{G}$ \\
\hline & Triazophos & $\begin{array}{l}\text { Cotton, potato, coffee, citrus, } \\
\text { beans, corn, soybean, tomato } \\
\text { and wheat. }\end{array}$ & Hostathion $400 \mathrm{BR}$ \\
\hline \multicolumn{4}{|l|}{ Methyl carbamate } \\
\hline & Carbofuran & $\begin{array}{l}\text { Cotton, peanuts, rice, } \\
\text { bananas, potatoes, coffee, } \\
\text { sugar cane, carrots, beans, } \\
\text { tobacco, corn, cabbage, } \\
\text { tomato and wheat. }\end{array}$ & Furadan 50 GR \\
\hline & Carbosulfan & $\begin{array}{l}\text { Cotton, rice, potatoes, citrus, } \\
\text { beans, tobacco, papaya, } \\
\text { corn, soybeans, tomatoes, } \\
\text { wheat and grapes. }\end{array}$ & $\begin{array}{l}\text { Fenix, Marshal, Marshal } \\
\text { Star, Marshal 400, } \\
\text { Talisman }\end{array}$ \\
\hline & Thiodicarb* & $\begin{array}{l}\text { Cotton, oats, peanuts, barley, } \\
\text { beans, corn, sorghum, } \\
\text { soybeans and wheat. }\end{array}$ & $\begin{array}{l}\text { Cropstar, Saddler } 350 \text { SC, } \\
\text { Pontiac } 350 \text { SC }\end{array}$ \\
\hline \multicolumn{4}{|l|}{ Isothiocyanates } \\
\hline & Dazomet & Soil treatment & Basamid \\
\hline & Metam sodium & $\begin{array}{l}\text { Potato, carrot, tobacco, } \\
\text { strawberry and tomato }\end{array}$ & Bunema 330 CS \\
\hline \multicolumn{4}{|l|}{ Abamectin } \\
\hline & Abamectin* & $\begin{array}{l}\text { Cotton, garlic, corn and } \\
\text { soybeans }\end{array}$ & $\begin{array}{l}\text { Abadin } 72 \text { EC, Abamex, } \\
\text { Avicta } 500 \text { FS, Mantis } 400 \\
\text { WG, Vertimec } 18 \text { EC }\end{array}$ \\
\hline \multicolumn{4}{|l|}{ Fluoroalkenyl } \\
\hline & Fluensulfone & $\begin{array}{l}\text { Cotton, potato, coffee, sugar } \\
\text { cane, citrus, guava, chili, } \\
\text { pepper, soybean and tomato }\end{array}$ & $\begin{array}{l}\text { Nimitz TS, Blindado, } \\
\text { Legado }\end{array}$ \\
\hline
\end{tabular}

Based on: Agrofit (2018) * Registered as insecticides-nematicides.

body, they affect different internal organs (32). It should be noted that non-fumigant nematicides can also penetrate directly into the wall of the nematode body (32).

From the 1960s, new classes of nematicidal products were developed: organophosphates and carbamates, classified as non-fumigant nematicides (23). The major advantage of the organophosphates and carbamates is their reduced persistence as toxic molecules compared with chlorinated hydrocarbon nematicides (23). These agents are produced as granules or liquids or both. Caudusafos (an organophosphorus pesticide) comes as granules (Rugby 200 CS) and in liquid form (Apache $100 \mathrm{GR}$ ). These nematicides have a systemic action on phytonematodes and are effective even at low dosages than fumigants. Despite little or no phytotoxic activity, they are highly toxic to mammals and insects, which generates environmental problems (29).

\section{Mechanism of action}

The mechanism of action of a nematicide refers to the lethal effect of the product on specific processes in the nematode (Fig. 1) (32). Organophosphates and carbamates act as nematicides by inhibiting the enzyme acetylcholinesterase, causing the cession of nerve impulses and ultimately, the death of the nematode (33). However, abamectin also affects acetylcholinesterase, and has deleterious effects on ATPase activity, acting as a neurotoxin and triggering respiratory failure (33).

However, despite these effects, the mechanism of action attributed to abamectin is the 
blockade of the electrical impulse transmission between the nerve cell and the muscle, by the uninterrupted opening of the chloride channels in the cellular membranes, with little effect on muscle excitation unlike the organophosphates (23). Abamectin has been shown to inhibit egg hatching and cause paralysis of the juveniles (34), which is irreversible in nematodes of the genus Meloidogyne spp. (27).

Isocyanate acts in various ways in the cell, the main ones being the inhibition of electron transport in the electron transport chain, enzymatic inactivation, and signaling for the induction of cell apoptosis (35). The mechanism of the nematicides belonging to the halogenated aliphatic compounds, like methyl bromide, are similar to the isocyanates, serving as alkylating agents of proteins and, also, oxidizing the $\mathrm{Fe}^{2+}$ centers in the cytochrome, blocking respiration (36).

The mechanisms of action of nematicides are not always easily detected, because it may involve different sites of the nematode or the action of combined effects (23), as exemplified by abamectin and isothiocyanates.

Narcotic effects and behavioral changes in nematodes are also described for fumigant and non-fumigant nematicides. An example is the initial hyperactivity of the nematodes when in contact with the products, followed by decreased movement and paralysis of activities (29). The effect of aldicarb on Heterodera rostochiensis (Woll.) inhibited the nematoid body activity and generated abnormal movement of the stylet (37). Other effects observed were the delays in the molting process, metabolic toxicity, and a reduction in hatch and egg production (38).

Nematicides containing the active ingredient fluensulfone in its composition, the more recently registered control agent, act in a more distinct way, promoting changes in the constitution of the steroids of the nematodes, causing them to bind to intracellular nuclear receptors, inducing the nematode to enter the Dauer phase or remain irreversibly in the Dauer phase (39). The Dauer phase is a stage of resistance to stress conditions in which the nematode presents a decrease in its development over adverse conditions, and is not phytopathogenic (40).

The use of nematicides may not result in the promotion of irreversible damage to nematodes (19), particularly if the exposure to the product is short or at low concentration. Reversible effects can be observed in nematodes exposed to these conditions, and, thus, the animals can complete their normal recovery and reproduction (32). An example of this behavior was demonstrated in a study with carbamates (32).
Factors, such as plant exposure time to the pathogen, stage of development of the nematode, the location of the nematode, enviromment temperature, soil moisture, and composition, besides chemical, physical, and biological processes occurring in the soil, can affect the performance of nematicides (23).

\section{Application technologies}

The concept of using a volatile compound, such as nematicides/insecticides/fumigants for the management of pests and nematodes present in the soil arose from the need to dispose of the large quantity of chemicals left over from World War 1 (20). Thus, these products were applied directly to the soil, via fumigation, mainly in the USA (18).

Nematicides are highly toxic compounds that have a very low lethal rate $\left(\mathrm{LC}_{50}\right.$, the concentration that kills $50 \%$ of the animals). This property is particularly important for operators of application machines and people at risk of exposure to chemicals during their application (31).

Fumigant nematicides are applied to the soil as a solid, liquid or gas, before planting. The product vaporizes and disperses by fumigant action in the aerial spaces of the soil and then dissolves in the soil moisture, killing the nematodes (21). However, not all individuals of the present nematode population are killed, and not all of the fumigants are active on nematode eggs (21).

Non-fumigant nematicides are predominantly applied to soil as groove, band or broadcast applications (32). The applications are followed by washes in the soil for greater uniformity of distribution, where soil solution distribution is critical. The organic matter and a 2:1 clay content of the soil also affects the movement of non-fumigant nematicides (30). Thus, the products are more effective in fine-textured soil, because these soils have less organic matter and clay. The $\mathrm{pH}$ of the soil and water affect how much time an active ingredient remains in the soil. Active ingredients in the organophosphate and carbamate families are acidic, so they generally degrade more rapidly in soils with a $\mathrm{pH}$ above 7.0 (21).

Currently, other nematicide application strategies have been adopted, such as the use of lower doses of active principles and syrups, which reduce the risk of environmental pollution caused by nematicides without affecting the efficiency (23). Among them, the chemical management can involve treatment of the seeds (41), or direct application to the planting groove (42). The seed treatment promotes the protection of the initial roots against penetration of the nematodes present in the soil, ensuring a better initial development of 
the crop (43). In this approach, the applicability of the product is easier than the applying in soil.

Protection of root development in the first few days or weeks after germination is critical to the establishment of optimal productive potential (18). Therefore, the treatment of seeds with nematicides contributes positively to the initial development of the plant, as it reduces nematode penetration (43) and, consequently, its reproductive factor, thereby reducing its final population (44). Although this technique has a great advantage in the initial protection of the root system, the amount of product used in seed treatment is not enough to protect the crop during its entire cycle since the protection effect lasts around 25-30 days, and after this period, the roots was once again exposed to the attack of the phytonematodes (45).

In areas with high pathogen infestations, the application of nematicides in the liquid form can be an option because it ensures better distribution of the product in the groove, not only in the vicinity of the already treated seeds. Moreover, it can limit the mobility of nematodes (46).

When testing different positions of incorporation of nematicides in the planting groove, it was verified that cadusafos and fluensulfone provided control efficiencies greater than $50 \%$ and $80 \%$, respectively, for different nematodes (47). Regarding the phytotoxicity resulting from this process, no symptoms were detected in soybean plants when cadusafos and fluensulfone were directed apply in the seeding furrow (47). However, this application method still has little information about its phytonematode control, performance, selectivity (phytotoxicity), and crop response to yield.

\section{Conclusion}

The use of chemical control should be seen as another tool capable of nematode control. It is necessary that other control methods be integrated for better control. Although chemical control has started with compounds that are highly harmful to humans and the environment, new compounds that are less aggressive and more specific have been developed for phytoparasitic nematodes, making this tool safer for the producer, the consumer, and the environment.

\section{Authors' contributions}

LAE wrote most of the abstract, mechanism of action section, and conclusion, MK wrote most of the history of chemical control, mode of action, and application technologies sections, CD helped in translation, in writing some sections, and in the development of the figure.

\section{Conflict of interest}

The authors declared that they have no conflict of interest.

\section{References}

1. Bongers T, Ferris H. Nematode community structure as a bioindicator in environmental monitoring. Trends Ecol Evol. 1999; 4(6): 224:228. $\quad$ https://doi.org/10.1016/S0169$\underline{5347(98) 01583-3}$

2. Agrios GN. Plant pathology. 5th ed. Department of Plant Pathology, University of Florida. Elsevier Academic Press; 2005.

3. Bernard GC, Egnin M, Bonsi C. The Impact of PlantParasitic Nematodes on Agriculture and Methods of Control. Nematology: Concepts, Diagnosis and Control. 2017. https://doi.org/10.5772/intechopen.68958

4. Souza DSL. Seleção e avaliação funcional de fatores potencialmente envolvidos com interações entre plantas e nematoides parasitas. Tese em Biologia Molecular - UnB, Brasília. 2008; 146.

5. Jones JT, Haegeman A, Danchin EG, Gaur HS, Helder J, Jones MG et al. Top 10 plant-parasitic nematodes. Mol Plant Pathol. 2013; 14: 946-961. https://doi.org/10.1111/ mpp.12057

6. Arieira, GO. Diversidade de nematoides em sistemas de culturas e manejo do solo. Tese em Agronomia, UEM, Londrina. $\quad 2012 ; \quad 98 . \quad$ Available from: http://docentes.esalq.usp.br/sbn/ajuda/disgio.pdf

7. Lambert $\mathrm{K}, \mathrm{S}$ Bekal. Introduction to Plant-Parasitic Nematodes. The Plant Health Instructor. 2002 https://doi.org/10.1094/PHI-I-2002-1218-01

8. Almeida JE, Santos JM, Martins ABG. Influência do parasitismo pelo nematoide de galhas nos níveis de nutrientes em folhas e na fenologia de goiabeira 'Paluma'. Bragantia. 2011; 70 (4): 876-881. Available from: http://www.scielo.br/pdf/brag/v70n4/21.pdf

9. McCarter JP, Mitreva MD, Martin J, Dante M, Wylie T, Rao $\mathrm{U}$ et al. Analysis and functional classification of transcripts from the nematode Meloidogyne incognita. Genome Biology. 2003; 4:26. https://doi.org/10.1186/gb-2003-4-4-r26

10. Nunes HT, Monteiro AC, Pomela AWV. Uso de agentes microbianos e químico para o controle de Meloidogyne incognita em soja. Acta Sci Agron. (Online). 2010; 32(3): 403-409. https://doi.org/10.4025/actasciagron.v32i3.2166

11. Silva WRJ, Machado ART, Campos VAC, Zeri ACM, Campos VP, Oliveira DF. Volatile organic compounds for the control of Meloidogyne exigua in Coffea arabica. Trop. plant pathol. 2013; 38 (5): 375-386. [cited 01 Apr. 2018]. Available from http://www.scielo.br/scielo.php? script $=$ sci arttext\&pid=S1982 $\underline{56762013000500002 \& \operatorname{lng}=\text { en\&nrm }=\text { iso }}$

12. Dinardo-Miranda LL, Menegatti CC. Danos causados por nematoides a variedades de cana-de-açúcar em cana planta. Nematol Bras. 2003; 27(1): 69-73.

13. Abd-Elgawad MMM, Askary TH. Impact of phytonematodes on agriculture economy. Biocontrol Agents of Phytonematodes. CABI, Wallingford, UK. 2015.

14. Singh S, Singh B, Singh AP. Nematodes: A Threat to Sustainability of Agriculture. Procedia Environ Sci. 2015; 29: 215-216. https://doi.org/10.1016/j.proenv.2015.07.270

15. Ferraz LCCB, Brown DJF. Nematologia de plantas: Fundamentos e importância. Norma Editora, Manaus AM. 2016; p. 251. 
16. Rich JR, Dunn RA, Noling JW. Nematology: advances and perspectives. Tsinghua University Press, Xue Yan Building, Tsinghua University, Beijing, 100084, PR China, 2003.

17. Taylor AL. Nematocides and Nematicides - A history. Nematropica. 2003; 33 (2).

18. Starr JL, Koenning SR, Kirkpatrick TL, Robinson AF, Roberts PA, Nichols RL. The future of nematode management in cotton. J Nematol. 2007; 39:283-294.

19. Kim J, Mwamula A, Kabir M. Efficacy of Different Nematicidal Compounds on Hatching and Mortality of Heterodera schachtii Infective Juveniles. The Korean Journal of Pesticide Science. 2016; 20 (4): 293-299. https://doi.org/10.7585/kjps.2016.20.4.293

20. Taylor, AL. Nematocides and nematicides-histov. Florida Department of Agriculture and Consumer Services, Division of Plant Industry Memo Series. 1979; 11.

21. Jones RK, Fourie H, Spaull VW, Daneel MS, Waele D. Nematology in South Africa: A View from the 21st Century. (C) Springer International Publishing Switzerland. 2017. https://doi.org/10.1007/978-3-319-44210-5

22. Desaeger J, Dickson DW, Locascio SJ. Methyl Bromide Alternatives for Control of Root-knot Nematode (Meloidogyne spp.) in Tomato Production in Florida. . J Nematol. 2017; 49(2): 140-140.

23. Galbieri R, Belot JL. Nematoides fitoparasitas do algodoeiro nos cerrados brasileiros: biologia e medidas de controle. Instituto Mato-grossense do Algodão - IMAmt Boletim de P\&D. 2016; 3: 23.

24. Inomoto MM, Asmus GL. Controle de nematoides une resistência, rotação e nematicidas. Visão Agrícola. 2006; $47-$ 50. [cited 09 Jun. 2018]. Available from: http://nematologia.com.br/wp-content/uploads/2012/07/ma rimus.pdf

25. Dinardo-Miranda LL, Morelli JL, Landell MGA, Silva MA. Comportamento de genótipos de cana-de-açúcar em relação a Pratylenchus zeae. Nematol Bras. 1996; 20(2): 5258.

26. Vitti AJ. Tratamento de sementes de soja (Glycine max (L.) Merr.) com abamectina, tiabendazol e acibezolar-S-metil no manejo de nematoides. 2009; 120 p. Tese (Doutorado em Agronomia: Produção Vegetal) - Escola de Agronomia e Engenharia de Alimentos, Universidade Federal de Goiás, Goiânia.

27. Faske TR, Starr JL. Cotton root protection from plantparasitic nematodes by abamectin treated seed. J Nematol. 2007; 39: 27-30.

28. Agrofit, Ministério da Agricultura, Pecuária e Abastecimento. 2018. [internet] [cited 22 Jun. 2018]. Available from: http://agrofit.agricultura.gov.br/agrofit cons/principal agr ofit cons

29. Spurr HW. Mode of action of nematicides. In: Sasser, J.N. \& Carter, C.C. (Eds). An advanced treatise on Meloidogyne, v.1, Biology and Control. 1985; p. 269-276.

30. Tao T, Maciel GE. Interaction of Methyl Bromide with Soil.

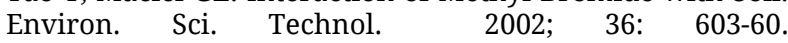
https://doi.org/10.1021/es010943b

31. Gowen SR. Plant Nematode Problems and their Control in the Near East Region - FAO. Plant Production and Protection Paper - 144. Part. I: Chemical control of nematodes: efficiency and side-effects. Karachi: University of Karachi. 1992.
32. Nowling JW. Movement and Toxicity of Nematicides in the Plant Root Zone. IFAS Extension - University of Florida. 1997; 8.

33. Nasr, HM. Toxicity and Biochemical Effect of Organophosphates and Bio-pesticides against Root-knot Nematode, Meloidogyne incógnita. J Pollut Eff. 2015; Cont: 4: 151. https://doi.org/10.4172/2375-4397.1000151

34. Cayrol JC, Djian JP, Frankowski C. Efficacy of abamectin B1 for the control of Meloidogyne arenaria. Fundam. Appl. Nematol. 1993; 16:239-246.

35. Aguiar NDC. Impacto do isotiocianato de alila sobre a comunidade microbiana e indicadores microbiológicos do solo. Tese (doutorado), Universidade Federal de Viçosa. 2012; 122.

36. Chitwood DJ. Encyclopedia of Agrochemicals. Nematicides. 3 Volume set. 2002; p. 1638: 1104-15.

37. Nelmes AJ. Behavioral responses of Heterodera rostochiensis larvae to aldicarb and its sulfoxide and sulfone. J Nematol. 1970; 2:223-227.

38. Huang SP, Van Gundy SD. Effects of Aldicarb and Its Sulfoxide and Sulfone on the Biology of Tylenchulus semipenetrans. J Nematol. 1978; 10: 100-106

39. Mangelsdorf DJ, Auchus RJ, Motola DL, Cummins CL, Sharma KK. Ligands for nematode nuclear receptors and uses thereof. United States Patent Application Publication. 2011; 22p. [cited 17 Jun. 2018]. Available from: https:/patents.google.com/patent/US20110028443

40. Karp X. Working with Dauer Larvae.” WormBook: the online review of C. elegans biology. PMC 2016; 1-19. https://doi.org/10.1895/wormbook.1.180.1

41. Cabrera JA, Klewnick S, Frimm C, Dababat AA, SikoraI RA. Efficacy of abamectin seed treatment on Pratylenchus zeae, Meloidogyne incognita and Heterodera schachtii. J Plant Dis Prot. 2009; 116: 124-128. https://doi.org/10.1007/BF03356298

42. Novaretti WRT, Reis AM. Influência do método de aplicação de nematicidas no controle de Pratylenchus zeae em soqueiras de cana-de-açúcar e definição dos níveis de dano e de controle. Nematol Bras. 2009; 33:83-89.

43. Corte GD, Pintol FF, Stefanello MT, Gulart C, Ramos JP, Balardin RS. Tecnologia de aplicação de agrotóxicos no controle de fitonematoides em soja. Cienc Rural. 2014; 44(9): $\quad$ 1534-1540. $\quad$ https://doi.org/10.1590/01038478cr20130738

44. Bortolini GL, Araújo DV, Zavislak FD, Júnior-Romano J, Krause W. Controle de Pratylenchus brachyuru via tratamento de semente de soja. Enciclopédia Biosfera. 2013; 9(17); 818-830

45. Kubo R. K, Machado ACZ, Oliveira CMG. Efeito do tratamento de sementes no controle de Rotylenchulus reniformes em duas cultivares de algodão. In $7^{\circ}$ Congresso Brasileiro de Algodão. Foz do Iguaçu, PR. 2009.

46. Corte GD. Tecnologia de aplicação de agrotóxicos no controle de fitonematoides em soja. Dissertação (Mestrado), Universidade Federal de Santa Maria, Santa Maria. 2013; p. 61. [cited 14 May. 2018]. Available from: https://repositorio.ufsm.br/bitstream/handle/1/7572/DALLA \%20CORTE\%2c\%20GERSON.pdf

47. Santos OS. Aplicação em sulco de nematicidas em soja. Dissertação (Mestrado), Universidade Federal de Santa Maria - RS, Centro de Ciências Rurais. 2015; 51. 